\title{
PIRACY AROUND AFRICA'S WEST AND EAST COASTS: A COMPARATIVE POLITICAL PERSPECTIVE
}

\author{
Prof Theo Neethling, \\ Department of Political Science, University of the Free State
}

\begin{abstract}
The study of politics, or political science, focuses on both the abstract theories and practical operation of government and politics. The phenomenon of piracy on the east and west coasts of Africa brings an important scholarly issue to the fore, namely the significant roles of non-state actors in national, regional and global issues and politics. The phenomenon of maritime piracy along Africa's coastal areas is indeed of great strategic and political-economic interest - specifically since globalisation and maritime trade show a close interface. This article examines the similarities and differences relating to the phenomenon of piracy on the east and west coasts of Africa from a Political Science perspective by assessing, interpreting and appraising the phenomenon, and ascribing meaning to recent events and developments. It also explains the current insecurity off the west and east African coasts and closes with a brief comparison between the two regions under review. It concludes with the point that most security challenges confronting Africa have their origin in the lack or failure of governance as states are the primary actors and agents of good order at sea. Thus the required good order at sea should be viewed as a function of how states, such as Somalia and Nigeria, exercise their jurisdiction at sea to secure busy sea lanes and also to protect the safe harvesting and extraction of resources.
\end{abstract}

\section{Introduction}

Maritime piracy is an age-old phenomenon and has posed challenges for mariners as long as ships have gone to sea. In ancient times, Julius Caesar was captured by pirates and held for ransom. In more recent times, but still in the historical past, peaks in piracy include the Barbary pirates, who operated from North Africa, in the $17^{\text {th }}$ and $19^{\text {th }}$ centuries. These pirates challenged merchant shipping from the Spanish Main (Spanish colonies in the Americas) to the Barbary Coast. In Asia, the famous "pirate queen", Cheng I Sao, commanded a fleet of hundreds of vessels. ${ }^{1}$ Today, in several strategic "choke points", like the Malacca Straights, 
large, slow-moving ships are still easily approached and sometimes boarded by armed pirates in much smaller agile and quicker boats. ${ }^{2}$ As far as the prevalence of maritime piracy is concerned, the period 2008 to 2009 will be remembered for a surge in piracy not seen in generations. Piracy and armed robbery have threatened vital sea lines of communication and trade interest, and the severity of the crisis has compelled relevant role-players in the international community to actively pursue solutions to the problem.

Until the alarming increase in attacks and hijackings in Somali waters ${ }^{1}$ in recent years, few people were actually aware that maritime piracy has continued into the current era. Since early 2008, Somali pirates especially gained worldwide attention and interest. Of the almost 300 ships that were attacked in 2008, 111 were around the Horn of Africa and in the Gulf of Aden. ${ }^{3}$ Since 2009, attacks continued and a number of ships from various nations were seized. In dramatic fashion, pirates use fast-moving skiffs to pull alongside their prey and scamper on board with ladders or grappling hooks. Once on board, they hold crews at gunpoint until a ransom is paid, with amounts varying normally between US\$1 million and US\$2 million, but even as high as US\$4 million. "All you need is three guys and a little boat, and the next day you're millionaires". ${ }^{4}$

Towards the end of 2008, the dramatic standoff between US naval warships and Somali pirates demanding a US\$20 million ransom for a hijacked Ukrainian ship loaded with Russian tanks specifically highlighted and focused the world's spotlight on piracy in the Gulf of Aden. ${ }^{5}$ The hijacking south east of Mombasa, Kenya, of the Sirius Star, a Saudi super tanker carrying two million barrels of oil, also towards the end of November 2008, furthermore stressed the prevalence and danger of piracy around Africa's east coast. In this particular case, a ransom of $\$ 25$ million for the release of the vessel was claimed, ${ }^{6}$ although an amount of $\$ 3$ million was eventually paid to the pirates. Another incident that specifically highlighted the reality and dangers of piracy on the east coast of Africa occurred in mid-April 2009 when Captain Richard Phillips of the Maersk Alabama was dramatically rescued by US Navy SEALS during which mission three Somali pirates were killed. ${ }^{7}$

Generally, African waters harbour important seaways of growing maritime insecurity, namely the coast off the Horn of Africa and the Gulf of Aden (east coast of Africa), and the Gulf of Guinea (west coast of Africa). It should also be noted that until recently, maritime piracy has been largely prevalent in Asia, but in 2007

${ }^{1}$ References are often made to piracy in Somali waters, but it should be noted that the pirates are spread across thousands of square kilometers of water, stretching from the Gulf of Aden, at the narrow doorway to the Red Sea, to the Tanzanian border along the Indian Ocean. 
the number of pirate attacks in Africa surpassed those in Asian waters. Attacks have been largely concentrated in waters off the coast of Nigeria and Somali, but are not limited to those areas. ${ }^{8}$ Of special importance is that maritime insecurity in general, and in African waters in particular, has been growing at a disturbing rate and threatens the global flow of goods and services across the world's shipping lines. In this regard, globalisation and maritime trade show a close interface since the bulk of international goods and services - more than 80 per cent - travel by sea. ${ }^{9}$ In view of this, Potgieter rightly argues that pervasive maritime insecurity is a significant threat to security in Africa, to its development, to the shipping around Africa's coast and to maritime resources. ${ }^{10}$

The phenomenon of maritime piracy along Africa's coastal areas is indeed of great strategic and political-economic interest - specifically since globalisation and maritime trade show a close interface. This makes the sea lanes off the Horn of Africa and the Gulf of Aden as well as the Gulf of Guinea of the utmost importance as much of the flow of maritime traffic along the African coast travels through these busy lanes or regions. This article aims at exploring the similarities and differences relating to the phenomenon of piracy on the east and west coasts of Africa from a Political Science perspective by assessing, interpreting and appraising the phenomenon, and ascribing meaning to recent events and developments. It also explains the current insecurity off the west and east African coasts and closes with a brief comparison between the two regions under review. In this regard, perspectives and conceptual tools from the sub-discipline of Comparative Politics (in the scholarly discipline of Political Science) will be used to execute the investigation.

\section{The phenomenon of modern-day maritime piracy}

According to Onuoha, there is no single definition of piracy that is accepted by all states, organisations and scholars. ${ }^{11}$ A fundamental issue for piracy research that emerged in the past years was the strength and weaknesses of the divergent definitions of piracy held by significant role-players, such as the International Maritime Organisation (IMO) and the International Maritime Bureau (IMB). The IMO, a specialised agency of the United Nations (UN), obviously conforms to the definition of piracy in the United Nations Law of the Sea (Art.101) (UNCLOS), which contains the following:

"Piracy consists of any of the following acts:

(a) any illegal acts of violence or detention, or any act of depredation, committed for private ends by the crew or the passengers of a private ship or a private aircraft, and directed: 
(i) on the high seas, against another ship or aircraft, or against persons or property on board such ship or aircraft;

(ii) against a ship, aircraft, persons or property in a place outside the jurisdiction of any state;

(b) any act of voluntary participation in the operation of a ship or an aircraft with knowledge of facts making it a pirate ship or aircraft;

(c) any act of inciting or intentionally facilitating an act described in subparagraph (a) or (b)."12

The IMO definition of piracy restricts it to illegal acts of violence or detention committed on the high seas, or outside the jurisdiction of a coastal state, committed for private ends by the crew or passengers of a private ship, directed against another ship. At the same time, the IMO definition views and specifies acts of violence or detention committed against ships that occur within the jurisdiction of a state as armed robbery against ships. Thus any unlawful act of violence or detention or any act of deprivation at anchor, off ports or when underway through a coastal state's territorial waters is not specified and viewed as piracy. ${ }^{13}$

The definition used by the IMB, a specialised division of the International Chamber of Commerce, is much broader. It defines piracy as "an act of boarding or attempting to board any ship with the intent to commit theft or any other crime and with the attempt to or capability to use force in the furtherance of that act". ${ }^{14}$ The IMB definition is certainly important, as the IMB is the world's foremost agency for exchanging and collecting information on maritime crime. Its definition is more inclusive than that of the $\mathrm{IMO}^{15}$ and, with its wider definition, the IMB allows for a more comprehensive picture about maritime crime as many illegal acts occur within territorial waters. Although the IMB's definition is not recognised by international law, many scholars progressively adopt this approach to defining maritime piracy, and the data used in this article are likewise based on the definition of the IMB.

Some scholars or role-players also attach the phenomenon of piracy to terrorism. The Council for Security Co-operation in the Asia Pacific (CSCAP), an informal mechanism for scholars, officials and others to discuss political and security issues, produced an extensive definition for what is termed "maritime terrorism". Maritime terrorism is defined as

... the undertaking of terrorist acts and activities within the maritime environment, using or against vessels or fixed platforms at sea or in port, or against any one of their passengers or personnel, against coastal facilities or settlements, including tourist resorts, port areas and port town or cities. ${ }^{16}$ 
Maritime terrorism is, however, motivated by political goals beyond the immediate act of attacking a maritime target. ${ }^{17}$ Generally, piracy is not necessarily underpinned or driven by political goals, but this may be of importance when studying piracy in the African context, specifically piracy off the Nigerian coast.

Lastly, the phenomenon of maritime piracy is closely associated with the term "maritime security". Maritime security can be defined as the freedom from or absence of those acts which could negatively impact on the natural integrity and resilience of any navigable waterway, or which undermine the safety of persons, infrastructure, cargo, vessels and other conveyances legitimately existing in, conducting lawful transactions on, or transiting through territorial and international waterways. It therefore implies unhindered oceanic trade and safe navigation of people, cargo, vessels and other conveyances. ${ }^{18}$ This said, maritime security is important for stability within the maritime domain. It is also a prerequisite for the economic utilisation of the sea, as it limits threats such as illegal fishing, pollution, piracy, asymmetrical threats and other criminal activities. The challenge to create order onshore and at sea is thus important. ${ }^{19}$

\section{Clarifying Comparative Politics}

In the discipline of Political Science, the study areas of Comparative Politics or Comparative Analysis include the notion of the actual act of comparison. It encapsulates a search for similarities and differences between and among political phenomena. These include political institutions, political behaviour and political ideas. The study of Comparative Politics is useful because it gives the researcher or scholar a broader perspective of political phenomena and political behaviour, which could contribute a great deal to both an understanding and appreciation of phenomena under review. Researchers or scholars can, therefore, discover broader issues and perspectives relating to political behaviour than one may find in more narrowly defined studies. ${ }^{20}$

In studies of Comparative Politics, the focus is mostly upon what governments do. This means that comparisons may be made between governments of different nations, governments at various stages of development or governments and policy over time. Another thrust is oriented to political behaviour. The focus may be on political stability, political elites, leaders in politics and so forth. Of great interest to political scientists are "analytical" systems, which could be defined as groups or objects that are connected with one another in an analytical way. Although nation-states are convenient to study because we can find them on a map and their borders are clearly defined, many of the subjects of comparative political analysis do not lie clearly within the framework of national borders. ${ }^{21}$ The phenomenon of piracy puts this in proper context. 
As already stated, modern-day maritime piracy off the African coast is certainly not confined to waters off the Horn of Africa and in the Gulf of Aden. Piracy is also significantly prevalent in the Gulf of Guinea, a sea lane that has an important connectivity with oil transportation. This will be explored in the sections below.

\section{Piracy in the Gulf of Aden and off the Horn of Africa}

Piracy figures for 2009, recorded up to October of that year, have passed the total number of attacks globally recorded in 2008. The Annual Report of the IMB also revealed that the total number of incidents in which guns were used had risen by more than 200 per cent, compared to the corresponding period the previous year. ${ }^{22}$ From the IMB's figures for 2008 and 2009, it is clear that the lion's share of hijackings have taken place off the coast of Somalia, covering the area off the country's east coast in the Indian Ocean to the Gulf of Aden. Attacks took place as far as the area off the coast of Oman, although they can be attributed to suspected Somali pirates. $^{23}$

According to Onuoha, pirate attacks have increased both horizontally and vertically around the Somali coast. Horizontally, pirates have acquired weaponry and high-tech gadgetry that put them in a position where they are able to launch attacks as far as the Gulf of Aden and deep into the Indian Ocean. The weapons that they use range from automatic weapons to rocket-propelled grenades, while they also rely on global positioning systems and satellite phones to carry out their attacks. Their mode of operation often involves the use of large "mother ships" (mostly converted fishing vessels), which follow the targeted ship and on approaching the target, they dispatch smaller speedboats that move in closer to enable the pirates to board the ship. Vertically, attacks have increased in the sense that all kinds of vessels, including cargo vessels, bulk carriers, tankers, fishing vessels, sailing yachts and tugboats are targeted. Even vessels from the UN's World Food Programme have not been spared from pirate attacks. ${ }^{24}$ Against this background, Wambua states that previously vessels keeping at least 50 nautical miles from the coast were considered safe from pirate attacks, but the range has increased to at least 200 nautical miles. $^{25}$

In view of the above, shipping, oil and insurance firms have been impacted along the east coast of Africa by a significant and long-term increase in pirate attacks mounted against off-shore platforms, tankers and cargo vessels travelling through the shipping lanes. Such attacks have amounted to global losses of up to US\$16 billion annually. ${ }^{26}$ Piracy off the east coast of Africa obviously has some serious implications for international trade. The global merchant shipping supply line was impacted through a steep rise in insurance premiums. Several 
companies even suspended transits through the Suez Canal, rather sending their ships around the Cape of Good Hope, thereby incurring an additional 10 to 14 days of transit time. Revenue for the Suez Canal dropped from US\$426 million in 2007 to US\$391 million in 2008 as a result of piracy, in addition to the worldwide financial meltdown. ${ }^{27}$

This prompted the international insurance giant, Lloyds, to state that, if current piracy levels continue, companies everywhere would pay an increasing "piracy tax" to maintain their global trading networks over the next few years, thereby adding an additional strain to the burden created by the international economic meltdown. Moreover, Lloyds also warned that it is likely that "the audacious tactics of Somali pirates, which have been widely reported, will be mimicked in other parts of the world that have been ravaged by the recession." 28 All of this illustrates that economies are more interdependent today than ever before in history and that the opportunity for wealth creation is multiplied, but also that the opportunity for destabilising events and shocks can be transmitted from country to country. ${ }^{29}$

Historically it should be noted that attacks on vessels off the east coast of Somalia is not a new phenomenon, but a more structured form of piracy that emerged in the mid-1990s. In some instances, fishermen got dismayed at the inability of the central government to protect their country's fishing resources and started to take matters into their own hands. They then realised that robbing foreign vessels was a lucrative way of making up for lost income. ${ }^{30}$ In other instances, pirates claimed that they were the authorised "coastguard" patrolling the 200nautical-mile exclusive zone of Somalia charged with the responsibility of protecting Somalia's fishing resources. Fishing vessels were attacked for purportedly poaching in Somali waters, with ransoms demanded for the release of the boats and their crewmen. ${ }^{31}$ Early in 2006 , the "Somali coastguard" captured nine Yemeni fishing boats and claimed that they were illegally fishing in the waters off Somaliland. Taiwanese and South Korean fishermen were lured into Somali waters in pursuit of lucrative yellow-fin tuna, which likewise led to incidents of piracy, but from the Somali side it was claimed that they were merely protecting their own fishing resources and that the perpetrators were, therefore, "fined". ${ }^{32}$ This eventually turned into a situation of Somali attacks on whomever they came across with no differentiation between nationalities. It thus led from piracy as a fairly "insignificant occurrence" in terms of attacks on vessels that were fishing illegally to high-level diplomatically related maritime crimes of a most serious nature. ${ }^{33}$ The significance of attacks became evident when a Dutch-operated container ship outmanoeuvred pirates attacking it with rocket-propelled grenades 450 miles east of Dar es Salaam on the open sea on 7 December $2008 .^{34}$ 
The political-economic impact of piracy on the east coast of Somalia is clear: piracy is dangerous, threatens property and ships, endangers critical sea lines and the free flow of commerce, and is regionally destabilising. Moreover, considering that 80 per cent of the world's global trade moves by water, piracy is corrosive to political and social development, thwarting economic growth and has already led to companies considering forgoing the Suez Canal. Much like the Barbary pirates who operated from the Ottoman principalities in North Africa in the $17^{\text {th }}$ and $19^{\text {th }}$ centuries and who inflicted a devastating regional economic impact, present-day piracy has a negative effect on many nations and vital global merchant shipping routes. Piracy causes nations, companies and ships to take alternative routes that add days and millions of dollars to transit their merchandise. Furthermore, some crews started to demand double wages to sail near the Somali waters and these costs are usually added to the value of the goods being shipped. ${ }^{35}$ Obviously, in this context, the more than 200 vessels a day that pass within miles of the Somali coast became a global concern and security threat, and this situation poses immense challenges to international role-players in the global political economy. ${ }^{36}$

Furthermore, because of the value of marine resources and trade to the Horn of Africa region, the situation off the Somali coast is also resulting in lost wealth and income in many spheres of economic activity for Somalia. The impact has specifically been negative for fishing, trade, import and export, and lost revenues, duties and taxes. Other countries in the region also recorded vast losses due to illicit activities at sea. Kenya, for example, has claimed that piracy caused the country substantial losses that amount to billions of Kenyan shillings. Mozambique and Tanzania have also lost more than a billion US dollars per year. Obviously, tourism in the region is negatively affected, especially leisure travel, from yachts to chartered voyages and large ocean liners. ${ }^{37}$ In one of the most newsworthy incidents towards the end of 2009 , the tourism industry was shocked by the fate of a British couple whose yacht was hijacked on its way to Tanzania, and ransom of $\$ 7$ million demanded. In this case, high-seas hijackings persisted despite an international armada of warships deployed in the region by the US, the European Union, the North Atlantic Treaty Organisation, Japan, South Korea, China and other nations. $^{38}$

The political impact of piracy in the Somali context also extends to the local (micro) level. The annual per capita income in Somalia is estimated to be US $\$ 650$, while a single pirate attack can yield US\$10 000 for a working-level pirate. Obviously, many Somalis involved in piracy have financially benefited from successful off-shore attacks on vessels: 
Residents in Garoowe, a town south of Boosaaso, say pirates drive the biggest cars, run many of the town's businesses and throw the best parties. The temptation is huge for Somali men and criminals are flocking to Boosaaso and other pirate dens along the craggy shore, turning these sapphire-blue waters into the most dangerous shipping lanes in the world ... The pirates at sea are savvy, fearless and rich, with the latest gadgetry like hand-held GPS units. And they are united. The immutable clan lines that pitted Somalis against another for decades are not a problem. "We work together," said Jama Abdullahi, a jailed pirate. "Good for business, you know?",39

The question remains: what is the root cause of the maritime insecurity off the Somali coast? The history of contemporary Somalia has been well researched and documented and will not be addressed here. Suffice to state that Somalia has been crippled by war, inter-clan rivalry and state weakness since the country has been without an effective government - and sound governance - since 1991. Consequently, Somalia has effectively continued in a downward spiral towards a lack of social cohesion and an inability to exercise central control and authority over rural regions and borders. ${ }^{40}$ In the words of Guyo, "Somalia provides a legal and security dilemma which is likely to continue as long as there is no effective government in Somalia." ${ }^{41}$ It is often reported in the media that the country is in chaos, countless children are starving and people are killing one another in the streets of Mogadishu, the capital, for a handful of grain. ${ }^{42}$ Order, according to McGowan, Cornelissen and Nel, presupposes government, whilst sound governance in turn presupposes authority, which is the right to enforce obedience. ${ }^{43} \mathrm{Clearly}$, any measures to deal with piracy are "intrinsically linked to the economic and political crisis in Somalia" and "security operations off the coast will be of limited significance unless there is restoration of effective governance in Somalia."

In view of the above, piracy and insecurity on the east coast of Africa seem to relate a great deal to the scholarly construct of weak and so-called failed states to effectively govern their territories and borders - in the case of Somalia, specifically, to patrol and control its territorial waters. In the words of Potgieter, "This (maritime insecurity) is probably nowhere more evident than the case of Somalia, where the lack of stability ashore has impacted negatively on the situation at sea." ${ }^{45}$ Thus, the absence of effective government in Somalia and sound governance (the latter denotes the process by which the state and government machineries are set in motion) have led to a marked increase in piracy as both a crime of opportunity and also a form of organised crime. ${ }^{46}$ This should be viewed in the context of the fact that Somalia does not have a strong national armed force or a police force that can enforce government authority. As far as the Somali navy is 
concerned, it was initially established and equipped with four Soviet fast-attack craft and smaller vessels, but most of the equipment became unserviceable after the departure of Soviet naval personnel in 1977. Since 1991, the Somali navy no longer exists. ${ }^{47}$ Against this background, analysts point out that, around the Horn of Africa, ungoverned or weakly governed continental spaces (Somalia in particular) are blending with an ungoverned maritime landscape. The area is almost totally deprived of naval means and such limitations have resulted in an inability to establish some semblance of order. ${ }^{48}$

\section{Piracy in the Gulf of Guinea}

It has already been said that the period 2008 to 2009 will be remembered for a surge in piracy not seen in generations. In May 2008, the BBC reported that, according to statistics provided by the IMB, Nigeria accounted for 10 of the 49 attacks registered worldwide in the first quarter of 2008, which translates into a figure of more than 20 per cent. ${ }^{49}$ Despite the prevalence of maritime piracy off the Nigerian coast and in the wider Gulf of Guinea, piracy in this region tends to receive less public attention than in the case of the Horn of Africa and in the Gulf of Aden. ${ }^{50}$ Still, the IMB's Report on Piracy and Armed Robbery Against Ships for the period 1 January to 30 September 2009 states, "Nigeria continues to remain an area of high concern." its prized oil industry a particular target" because the raiders have exposed flaws in the country's security. ${ }^{52}$ Africa News Updated reported as follows:

Security has been getting worse for months, investment has been declining and the currency, the naira, has grown weaker as oil prices falter. On 23 May, a week after the fighting began, state governors from the Delta met with foreign diplomats and the media. They blamed the crisis largely on other government's failure to address bunkering (the theft of oil from pipelines) and small-arms trafficking. Hitherto, they had mostly blamed the petroleum industry.

Unlike piracy off the Somali coast, piracy in Nigerian waters further off the West African shoreline should firstly (broadly) be viewed against the background of the Gulf of Guinea as a region with a large population and abundant energy resources typified by the proximity of large oil producers (Nigeria and Angola), maturing oil producers (Congo Brazzaville), mature oil producers showing signs of decline (Cameroon and Gabon), and new producers (Equatorial Guinea and Chad). Located off the Gulf of Guinea, these West African countries border an important sea lane that has an important connectivity with energy commodities. ${ }^{53}$ It 
is secondly (more narrowly) linked to oil development and the resulting socioeconomic and environmental conditions in the Niger Delta, an area of dense rainforest at the southern tip of Nigeria comprising nine of Nigeria's thirty-six states. In this regard, there is a clear link between a feeling of alienation and marginalisation on the part of some inhabitants of the Delta region and the occurrence of militancy and criminality in the Delta region, with specific reference to hostage-taking (especially that of employees of foreign oil multinationals) as a common criminal activity ${ }^{54}$ - and this extends to piracy in the Gulf of Guinea on a broader scale.

Against this background, conflict in the Niger Delta (and piracy off the Nigerian coast) should be viewed in the context of poverty, political disenfranchisement and the easy availability of firearms and armed conflict over oil. It should further be understood against the background of previous governments largely ignoring the Niger Delta, partly because its geography made it relatively inaccessible, and also following bad governance and corruption in Nigeria after years of military rule. ${ }^{55}$ The federal government of Nigeria and the oil companies split profits roughly 60/40, and the money is supposed to benefit the Delta inhabitants, but this rarely occurs. ${ }^{56}$ As far as piracy is concerned, Vreÿ summarises this strikingly: "Nigerian politics on land directly result in offshore actions, causing the hub of insecurity." 57

Despite having raked in more than US\$250 billion in oil revenues since independence, many Nigerians remain very poor and the largest of the Delta's ethnic groups claim that the country's oil revenues are mismanaged by politicians. These claims result in conflict between oil multinationals and the government on the one hand, and communities on the other. ${ }^{58}$ In most of the attacks, the Movement for the Emancipation of the Niger Delta (MEND), the best-armed group in the region, was responsible for attacks on oil pipelines of multinationals, such as Chevron, but also on vessels off the Nigerian coast chartered by oil-multinationals. Boats in waters of neighbouring Cameroon have likewise come under attack. Reminiscent of piracy on the east coast of Somalia, militants attack vessels and strip them of valuables, taking hostages for ransom. ${ }^{59}$

Although claiming that they are fighting for a bigger share of Nigeria's oil wealth, many attacks are carried out by criminal gangs looking to extort money from oil companies. ${ }^{60}$ In both cases of piracy on the east and west coasts of Africa, a combination of access to resources and criminal activity thus seems to play a role and both these regions have become contested terrains where armed pirates on small, agile and quick boats are using AK47s and RPGs to launch attacks on either tankers or cargo vessels. Nigerian officials admitted that Nigeria is ill-equipped to combat pirates who trouble the west coast with speed boats, modern machine guns and 
radios where they target tankers, trawlers and oil-industry back-up vessels. The most pirate-infested waters or zones are around the economic capital, Lagos, and the oil-rich waters of the southern Niger Delta (Port Harcourt). But the pirates do not confine themselves to floating targets; they also attack banks in towns along the coast. Similar to the case of piracy on the east coast of Africa, this has brought together top naval officials and governmental and non-governmental role-players, specifically from the Nigerian navy, the Nigerian Maritime Security Agency and the IMB, to discuss measures to protect Nigeria's $853-\mathrm{km}$ coastline.$^{61} \mathrm{In}$ addition, the US Navy with its Africa Partnership Programme (now part of the US Africa Command) is in a strong working relationship with the Nigerian Navy, as well as other relevant African navies. ${ }^{62}$

Although pirates in Nigerian waters often claim to be fighting for a fairer distribution of Nigeria's vast oil wealth and as a protest against the damage caused by oil production in the Delta, observers just as often point out that the lines between political grievances and criminality in the Gulf of Guinea are blurred. ${ }^{63}$ Nincic argues that not all pirate attacks in the region are politically motivated. In fact, the majority of attacks have been motivated by financial and not political gains. Massive unemployment and a lack of meaningful economic opportunities are the order of the day in Nigeria, especially in the Delta region. This has drawn young people into a variety of maritime criminal activities, including kidnapping, piracy and bunkering (oil theft). Crime and opportunity are motivational factors as many armed groups in the Delta region view maritime crime as a purely money-making endeavour. Pirates are often young unemployed men without job opportunities who admit that they were enticed into pirate gangs by monetary gains, fancy cars, luxury consumer goods and weapons. Against this background, Nincic points towards three areas of impact, namely oil production, fishing and seaborne traffic off the coast of Nigeria. ${ }^{64}$ Firstly, oil production in Nigeria has dropped by some 20 per cent since 2006, and illegal maritime activities have cost the Nigerian economy millions of dollars. It is estimated that the figure amounts to \$202 million between 2005 and 2008. Much of this cost is borne by the oil companies and the Nigerian government, but the loss in revenue means less funding for social and economic development for much needed development in the Niger Delta.

Secondly, maritime piracy impacts very negatively on the country's local fishing economy. Attacks on fishing vessels include theft of fish cargoes, engines and other material on board. In some instances, fishermen are also killed. Fishing is important as it is the second highest non-oil export industry in Nigeria, and attacks on fishing trawlers have reached the point where the captains of many fishing boats refuse to put to sea. Many trawlers have been idle since 2008, and this resulted in job losses of approximately 50000 at one stage. It is estimated that attacks on fishing vessels in Nigerian waters are under-reported, although figures recorded by 
the IMB are disturbingly high. Attacks on fishing boats also have other negative effects, for instance seafood prices in Nigeria have skyrocketed because of the scarcity of fish, placing this important source of protein out of reach for many ordinary Nigerians.

As in the case of piracy on the east coast of Africa, maritime piracy off the Nigerian coast has a wider regional and even global impact. Shippers began to factor higher insurance premiums into their pricing, and increased shipping costs are typically passed on to consumers. ${ }^{65}$ This said, the sea lane through the Gulf of Guinea is of global importance. An extensive range of actors is active in the oil industry on and off the shores of the countries bordering the Gulf of Guinea, and currently, the safe transportation of gas and oil too is under threat. Maritime insecurity has been growing at a disturbing rate and as an important crossing for global maritime trade the growing attacks upon maritime vessels in this region obviously have an impact on global maritime economics. ${ }^{66}$

What is perhaps different from maritime piracy on the east coast of Africa is that, in the case of piracy in the Gulf of Guinea, aggressors like MEND and others (e.g. the Bakassi Freedom Fighters) use a deliberate campaign at sea to influence decisions about landward matters. In this regard, the oil industry in this region with its footprint clearly in the maritime domain - offers lucrative opportunities. Thus rebels extend their political agendas offshore, although their interests are heavily driven by a combination of greed and grievance in an important commercial environment along the African west coast. ${ }^{67}$

\section{Evaluation and conclusion}

Conventionally, the study of politics, or political science, focuses on both the abstract theories and the practical operation of government and politics. The phenomenon of piracy on the east coast of Africa brings another scholarly issue in the field and study of politics to the fore, namely the increasingly important roles of non-state actors in national or global issues and politics, such as ship-based piracy as an act of crime on the high seas. At the time of writing, Somali pirates attacked vessels off the north, east and south coasts of Somalia. Attacks have spread and taken place very far off the coasts of Kenya, Tanzania, the Seychelles and Madagascar. ${ }^{68}$ All kinds of vessels, including cargo vessels, bulk carriers, tankers, fishing vessels, sailing yachts and tugboats are targeted.

The prevalence of piracy off the Horn of Africa and in the Gulf of Aden should be viewed and understood in the context of the failure of government, which has resulted in a climate of insecurity in Somalia. ${ }^{69}$ This has led to the development of a criminal economy in Somalia and further afield. Furthermore, a situation of conflict in Somalia created an environment for violence in the maritime context. In 
other words, landward and maritime insecurity are intertwined, as insecurity on land eventually causes maritime insecurity. Scholarly speaking, weak regimes on land potentially or eventually give rise to weak maritime regimes. The resultant maritime insecurity then extends from the coast to the high seas and, in the case of Somalia, this has impacted on a very broad regional scale.

Piracy and insecurity in the Gulf of Guinea manifested in the form of attacks on ships, hostage-takings and destruction of energy infrastructure by rebels who- in some instances - extended their political agendas offshore. In a comparative context, maritime insecurity in the Gulf of Guinea is more politically driven than in Somalia, but then, as already pointed out, not all pirate attacks are directly or purely politically motivated. Located off the Gulf of Guinea, West African countries border an important sea lane that has an important connectivity with energy commodities. The region hosts Nigeria and Angola, sub-Saharan Africa's two largest oil producers, as well as other producers such as Gabon, Cameroon, the two Congos and Equatorial Guinea. This is different from the seas off the Horn of Africa in the sense that the West African region is located in a major and significant consumer market. In addition to energy resources, other commodities are also important, such as diamonds, the region's rainforest habitat and agricultural commodities, such as cocoa - all of which form hubs of economic importance to increasing needs in the fields of energy, population and food. Such hubs of activity draw crime and other competition as is clearly witnessed in the Gulf of Guinea.

Although not similar in all instances, piracy off the Nigerian coast shows some parallels with piracy off the east coast of Somalia and in the Gulf of Aden. Generally, more often than not, piracy occurs when there is poverty and a weak or non-existent government. Analysts and scholars rightly contend that piracy off the Somali coast manifests in the context of the dire economic situation within that country. It is also often pointed out that Somalia is a disaster, with crushing poverty and no functioning government or economy. ${ }^{70}$ Comparatively, the Nigerian state cannot be classified as a weak state, but, as indicated, the contemporary events of piracy in the Gulf of Guinea should be associated with the culmination of years of inattention, desperation and lawlessness in the area bordering the globally vital shipping route. In this regard, political disenfranchisement of the Niger Delta especially and the resulting economic, social and environmental conditions in the Delta, led to a situation which was earlier described as "the most deadly in the world". ${ }^{71}$ Despite having generated billions of dollars from oil revenues since independence, many Nigerians remain very poor and the largest of the Delta's ethnic groups remain firm in their claim that the country's oil revenues are mismanaged by politicians and that they are not sharing in the wealth generated by oil exploration. Again, this reiterates the point that insecurity on land - potentially - extends to 
maritime insecurity. Moreover, in the African context in general, where the absence of effective navies, coupled with a lack of co-operation among littoral states in the relevant regions is the order of the day, piracy has proliferated and poses serious challenges to the international community. ${ }^{72}$

An analysis of piracy in the international community should, however, not be confined or limited to maritime crimes of a serious nature. It is also not peculiar to the African continent and its coastal areas. In May 2009, media reports suggested, "[1]orry drivers on European roads face the same dangers of hijack as ships off the coast of Somalia.,"73 Organised crime groups see trucking as "easy pickings" involving low risk and high returns. Romania, Hungary and Poland suffered the heaviest losses, but the Netherlands, Britain, France and Italy also recorded incidents. It has also been reported that cargo theft has become an international crime, often with criminals from one country committing crime in another, offloading goods in a third and selling them in yet another country. Metals, like copper, are the preferred loot as such metals can be sold on the metal market. Other easily sold goods are alcohol, computers and branded clothing. ${ }^{74}$

Considering the characteristics of piracy off the coast of Somalia, challenges relating to cargo theft in the European context reveal many interesting dimensions, such as: ${ }^{75}$

- A fundamental issue is the free movement of goods. Road-related cargo crimes threaten this principle in Europe.

- There is no real co-ordination of effort or approach in terms of both prevention methods and intelligence sharing.

- Road cargo is not simply a crime problem, but an economic problem with many billions of euros lost each year.

- A partnership approach with the industry is required on a trans-national level. Road-related cargo crimes should be tackled in a co-ordinated manner involving both public and private role-players.

It is commonly known that deregulation and interaction with accelerating changes in communications and computer technology have reinforced the movement towards an integrated global market. At the same time, several other, less benign activities have also been globalised, including drug trading, terrorism and other forms of illicit trafficking. Thus the financial liberalisation that has created some kind of borderless world has also coincided with criminal activity, creating numerous problems for especially poorer countries. ${ }^{76}$

All of the above coincides with what several scholars have started to highlight in the current era of globalisation with regard to "increasingly qualified and contested forms of central authority and legitimacy". In developing countries specifically, economic liberalisation has provided new actors within political 
complexes with the opportunity to engage in a more direct, individualistic and competitive fashion with the global economy. Moreover, Manuel Castells argued that globalisation and "deregulation" has prompted the emergence of a globalised criminal economy. Though having different aims and effects, actions within this context share the same networked, adaptive and expansive character. ${ }^{77}$

In the final analysis it should be clear that the security of global waterways cannot be overemphasised. The ocean is a medium of transportation for important mineral resources, especially crude oil, and a source of food in the form of fishing. Africa straddles important sea lanes and the waterways off the west and east coasts of the continent have in recent years emerged as some of the world's most dangerous routes as vessels and crew members have been the targets of maritime pirate attacks. Of particular concern is the prevalence and increase in maritime piracy activities - horizontally and vertically - around the Horn of Africa and in the Gulf of Aden, but also in the Gulf of Guinea where the safe transportation of commercial goods, cargo and human lives is under constant threat. From the above analysis it is furthermore clear that the required good order at sea is directly dependent on good governance and efforts should be made to address governance by strengthening all the relevant institutions and mechanisms to tackle the root causes of maritime piracy in the affected regions. After all, most security challenges confronting Africa have their origin in the lack or failure of governance ${ }^{78}$ as states are the primary actors and agents of good order at sea. Thus the required good order at sea should be viewed as a function of how states, such as Somalia and Nigeria, exercise their jurisdiction at sea to secure busy sea lanes and also to protect the safe harvesting and extraction of resources, whether oil exploration or fishing, to contribute to the desired good order. ${ }^{79}$

\section{End notes}

${ }^{1}$ Nincic, D. 2009. Maritime piracy in Africa: The humanitarian dimension. African Security Review 18(3): 1.

${ }^{2}$ International Security Network. 2008. Private security takes to the sea [Online]. Available at www.isn.ethz.ch/isn/layout/set/print/content/view/full/73?id=54064\&lng=en \&ots591=4888CAAO-B3DB-1461-98B9-E2OE7B9C13D4 [20 May 2009].

${ }^{3}$ Wilson, B. 2009. Effectively confronting a regional threat: Somali piracy. Conflict Trends 1:1.

${ }^{4}$ Somalia's booming pirate economy. 2008. Sunday Times, 23 November: 19.

${ }^{5}$ International Security Network. 2008. Fighting Gulf of Aden piracy [Online]. Available at 
www.isn.ethz.ch/isn/layout/set/print/content/view/full/73?id=92452\&lng=en \&ots591=4888CAAO-B3DB-1461-98B9-E2OE7B9C13D4[19 May 2009].

${ }^{6}$ Onuoha, F. 2009. Sea piracy and maritime security in the Horn of Africa: The Somali coast and Gulf of Aden in perspective. African Security Review18(3):36.

${ }^{7}$ Wilson op. cit., pp. 13, 17.

${ }^{8}$ Nincic op. cit., p. 2.

${ }^{9}$ Vreÿ, F. 2009. Globalisation and maritime economics: Securing the maritime landscape. Strategy Insights 17(9): 1.

${ }^{10}$ Potgieter, T. 2009. The lack of maritime security in the Horn of Africa: Scope and effect. Strategic Review for Southern Africaxxxi(1): 66.

${ }^{11}$ Onuoha op. cit., p. 32.

${ }^{12}$ United Nations. 1982. United Nations Convention on the Law of the Sea [Online]. Available at www.imo.org/Facilitation/mainframe.asp?topic_id=362 [29 July 2010].

${ }^{13}$ Maritime Terrorism Research Center. 2009. Defining maritime terrorism [Online]. Available at www.maritimeterrorism.co.definitions/ [6 November 2009]; Gibson, J. 2009. Maritime security and international law in Africa. African Security Review18(3): 67.

${ }^{14}$ International Maritime Bureau. 2009. Piracy and armed robbery against ships: Report for the period 1 January to 30 September 2009. London: 4.

${ }^{15}$ Johnson, J. \& Pladdet, E. 2003. Maritime piracy in Asia. IIAS News, 4-6 September: 1 .

${ }^{16}$ Maritime Terrorist Research Center op. cit.

${ }^{17}$ Ibid.

${ }^{18}$ Onuoha op. cit., p. 32.

${ }^{19}$ Potgieter op. cit., p. 78.

${ }^{20}$ Mahler, G. 2008. Comparative politics. Fifth edition. London: Pearson/Prentice Hall: $3-4$.

${ }^{21}$ Ibid., pp. 7-15.

${ }^{22}$ ICC Commercial Crime Service. 2009. Unprecedented increase in Somali pirates activity [Online]. Available at www.ccccs.org/index.php?option=com_content\&view=article\&id=376:unprecedente d-increase-in-somali-pirate-activity \&catid=60:news \&Itemid $=51[6$ November 2009].

${ }^{23}$ ICC Commercial Crime Services. 2009. Piracy figures for 2009 surpass those for the previous year [Online]. Available at www.ccccs.org/index.php?option=com_content\&view=article \&id=376:unprecedente d-increase-in-somali-pirate-activity \&catid $=60$ :news\&Itemid $=51[6$ November 2009].

${ }^{24}$ Onuoha op. cit., p. 36.

${ }^{25}$ Wambua, P.M. 2009. Enhancing regional maritime cooperation in Africa: The planned end state. African Security Review 18(3): 49.

${ }^{26}$ International Security Network. Private security takes to the sea. op. cit. 
${ }^{27}$ Wilson op. cit., p. 12.

${ }^{28}$ Insurance Journal Newsletter Reporter. 2009. Lloyd's '360 report' analyses impact of global political instability. Insurance Journal [Electronic], 15 June. Available at www.insurancejournal.com/news/international/2009/06/15/101361.htm [17 June 2009].

${ }^{29}$ Commission for Global Governance. 1995. Our global neighbourhood: The Commission on Global Governance. Oxford: Oxford University Press: 137.

${ }^{30}$ Nincic op. cit. p. 9.

${ }^{31}$ Wilson op. cit., p. 12.

${ }^{32}$ Potgieter op. cit., p. 75.

${ }^{33}$ Wilson op. cit., p. 12.

${ }^{34}$ Potgieter op. cit., p. 73.

${ }^{35}$ Nincicop. cit., p. 5; Wilsonop. cit., pp.12-13.

${ }^{36}$ Wilson op. cit., pp. $15-16$.

${ }^{37}$ Potgieter op. cit., p. 76.

${ }^{38}$ Pirates demand $\$ 7 \mathrm{~m}$ for couple. 2009. Sunday Times, 1 November: 13.

${ }^{39}$ Somalia's booming pirate economy op. cit., p. 19.

${ }^{40}$ Ansems, A. 2008. Somalia 2008: Starting from scratch on the long and winding road to peace and democracy. Scientia Militaria 36(1): 95-96.

${ }^{41}$ Guyo, M. 2009. Taking the Somali pirates to court. ISS Today [Electronic], 15 April. Available at www.issafrica.org/index.php?link_id=5\&slink_id=7560\&link_type=12\&slin k_type=12\&tmpl_id=3 [15 April 2009].

${ }^{42}$ Somalia's booming pirate economy op. cit., p. 19.

${ }^{43}$ McGowan, P., Cornelissen, S. \& Nel, P. 2006. The study of international relations. In P. McGowan, S. Cornelissen \& P. Nel (eds.). Power, wealth and global equity: An international relations textbook for Africa. Third edition. Cape Town: UCT Press: 11.

${ }^{44}$ Guyoop. cit.

${ }^{45}$ Potgieter op. cit., p. 92.

${ }^{46}$ International Security Network. Private security takes to the sea. op. cit.

${ }^{47}$ Potgieter op. cit., p. 69.

${ }^{48}$ Vreÿ, F. 2009. Bad order at sea: From the Gulf of Aden to the Gulf of Guinea. African Security Review 18(3): 20.

${ }^{49}$ Nigerian pirates grab French ship. 2009. BBC [Electronic], 6 January. Available at at http://news.bbc.co.uk/2/hi2africa/7813139.stm [9 June 2009].[BBC News]

${ }^{50}$ Nincic op. cit., p. 8.

${ }^{51}$ International Maritime Bureau op. cit.

52 Nigeria becomes world piracy hot spot. 2008.Mail \& Guardian [Electronic], 20 May. Available at www.mg.co.za/article/2008-05-20-nigeria-becomesworld-piracy-hot-spot [9 June 2009].

${ }^{53}$ Vrey. Bad order at sea. op. cit., 22. 
${ }^{54}$ Ibaba, I.S. 2008. Alienation and militancy in the Niger Delta: Hostage taking and the dilemma of the Nigerian state. African Journal on Conflict Resolution 8(2): $11,22$.

${ }^{55}$ Bekoe, D. 2005. Strategies for peace in the Niger Delta [Online]. United States Institute for Peace Briefing, December. Available at www.usip.org/pubs/usipeace_briefings/2005/1219_nigerdelta.html [9 June 2009].

${ }^{56}$ Nincic op. cit., p. 8.

${ }^{57}$ Vrey. Bad order at sea. op. cit., p. 28.

${ }^{58}$ Kipkore. W. 2009. Prevention of further conflicts over access to natural resources. ISS Today [Electronic], 18 February. Available at www.issafrica.org/index.php?link_id=5\&slink_id=7299\&link_type=12\&slin k_type $=12 \&$ tmpl_id=3 [22 November 2009].

${ }^{59}$ Nigerian pirates grab French ship op. cit.

${ }^{60}$ Nigerian pirates grab French ship op. cit.

${ }^{61}$ Nigeria becomes world piracy hot spot $o p$. cit.

${ }^{62}$ US Africa Command. 2010. Plans underway for fourth year of Africa Partnership Station [Online]. Available at www.africom.mil/getArticle.asp?art=4709\& [29 July 2010].

${ }^{63}$ Analysis - pirates, gangs fuel Gulf of Guinea woes. 2009. Reuters [Electronic], 15 April. Available at www.reuters.com/article/africaCrisis/idUSL9951481.i [17 November 2009].

${ }^{64}$ Nincic op. cit., p. 7

${ }^{65}$ Ibid., pp. 7-8.

${ }^{66}$ Vreÿ. Globalisation and maritime economics. op. cit., p. 1.

${ }^{67}$ Vrë̈. Bad order at sea. op. cit., p. 24.

${ }^{68}$ International Maritime Bureau op. cit.

${ }^{69}$ Onuoha op. cit., p. 37.

${ }^{70}$ Wilson op. cit., p. 15.

${ }^{71}$ Nincicop. cit., p. 7.

${ }^{72}$ Onuoha op. cit., p. 37.

${ }^{73}$ Land pirates' target Europe's truck drivers. 2009. Sky News [Electronic],14 May. Available at http://news.sky.com/skynews/Home/World-News/LorryDrivers-In-Europe-Face-Same-Hijack-Dangers-As-Ships-Off-SomaliaCoast-Europol-Report-Says/Article/200905215281280 [1 June 2009].

${ }^{74}$ Europol: Cargo theft a big problem. 2009. Boston Globe [Electronic], 12 May. Available at www.boston.com/news/world/europe/articles/2009/05/12/europol_cargo_the ft_a_big_problem_on_highways [1 June 2009].

${ }^{75}$ Europol. 2009. Cargo theft report: Applying the brakes to road cargo crime in Europe. The Hague: 20.

${ }^{76}$ Commission for Global Governance op. cit., p. 10. 
Scientia Militaria, South African Journal of Military Studies, Vol 38, Nr 2, 2010. doi: 10.5787/38-2-91

${ }^{77}$ Duffield, M. 2000. Globalisation, transborder trade, and war economies. In M.

Berdal \& D. Malone (eds.). Greed and grievance: Economic agendas in civil wars. London: Lynn Rienner: 72.

${ }^{78}$ Onuoha op. cit., p. 43.

${ }^{79}$ Vreÿ. Globalisation and maritime economics. op. cit., p. 4. 